\title{
Taxonomic Reassessment of the Causal Fungus of Peach Fusicoccum Canker in Japan*
}

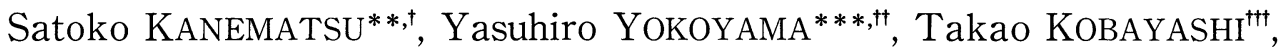 \\ Akira KUDO** and Yoshihiro OHTSU**
}

\begin{abstract}
The causal fungus of peach Fusicoccum canker in Japan had been identified as a species in the genus Fusicoccum. However, isolates from the canker of peach in Niigata had phialidic conidiogenous cells and produced beta conidia in vitro, which are typical in the genus Phomopsis. Comparative studies of the Niigata isolates and an French isolate of Phomopsis amygdali (synonym: Fusicoccum amygdali) in morphology of colony and conidia, pathogenicity to peach shoots revealed that these isolates are identical and belong to the same species. W- and G-type isolates from peach Phomopsis rot in Japan had alpha conidia similar to the Niigata isolates, but isolates of neither type caused symptoms of peach Fusicoccum canker in inoculation tests. It was concluded that the causal fungus of peach Fusicoccum canker is not a Fusicoccum but Phomopsis amygdali (Delacroix) Tuset et Portilla.
\end{abstract}

(Received March 29, 1999 ; Accepted July 9, 1999)

Key words : peach Fusicoccum canker, causal fungus, Phomopsis amygdali, taxonomy.

\section{INTRODUCTION}

Peach Fusicoccum canker was first reported in Japan by Harada and Kagiwata ${ }^{10)}$ in 1951 . The typical symptom of the disease was necrotic cankers at bases of peach shoots. Serious damage to the infected peach trees had been observed in Kanagawa around 1950. In Shizuoka, considerable damage to peach trees has been caused by this disease since $1977^{20}$. Since 1991, this disease has also been found in Niigata. In 1994, it completely destroyed the harvest in $10 \%$ of the peach fields in Niigata.

The causal fungus of the disease was identified as a species of the genus Fusicoccum Corda by Togashi et al. (1952), based on its pycnidia in erumpent stroma, small and oblong conidia but absence of beta conidia, which are typical of the genus Phomopsis (Saccardo) Bubáck ${ }^{10,22}$. However, taxonomic status of the fungus has not been investigated in detail so far, because the taxonomy of Fusicoccum is complicated ${ }^{9}$. The taxonomic status of the genus Fusicoccum and its type species has been a source of confusion in the past because the original material of the type species, $F$. aesculi Corda $^{5)}$ has not been reexamined ${ }^{21}$. Though the status of Fusicoccum is in contention, Fusicoccum is now often regarded as a conidial state of Botryosphaeria Ces. $\&$ de Not. ${ }^{3,11,15-17)}$.

Peach Fusicoccum canker fungus in Niigata clearly differed from Botryosphaeria isolates in colony and conidial morphology, and we found that the peach Fusicoccum canker fungus was rather similar to members of the genus Phomopsis. The typical characters of the genus Phomopsis are (1) phialidic conidial formation, (2) both alpha and beta conidia production and (3) a Diaporthe teleomorph ${ }^{25}$. So far, beta conidia and the ascogenous stage of the causal fungus of peach Fusicoccum canker have not been observed in Japan ${ }^{9,10,20)}$.

Canker and withering of young twigs in peach and almond trees have been reported in France ${ }^{7,12)}$, Italy $^{2)}$, Spain ${ }^{23)}$ and the United States of America ${ }^{4,6,8}$. Recently, the causal fungus of this disease has been transferred from Fusicoccum to Phomopsis and named P. amygdali (Delacroix) Tuset et Portilla, because of the presence of

\footnotetext{
* Contribution No. 1146 of the National Institute of Fruit Tree Science.

** National Institute of Fruit Tree Science, MAFF, Tsukuba 305-8605, Japan＼cjkstart農林水産省果樹試験場

*** Niigata Horticultural Experiment Station, Seiro, Niigata 957-0111, Japan＼cjkstart新潟県園芸試験場

† Present address: Apple Research Center, National Institute of Fruit Tree Science, MAFF, Morioka 020-0123, Japan 現在：農林水産省果樹試験場リンゴ支場

It Present address: Niigata Highland Agr. Tech. Center, Nakafukami, Tsunan, Nakaonuma, Niigata 949-8311, Japan 現在 : 新潟県農業総合研究所高冷地農業技術センター

It+ Department of International Agricultural Development, Tokyo University of Agriculture, Setagaya, Tokyo 156-8502, Japan＼cjkstart東京農業大学国際農業開発学科
} 
beta conidia and phialidic conidiogenous cells ${ }^{23)}$.

In Japan, still another disease by a Phomopsis sp., peach Phomopsis rot occurs. The pathogen also causes bud canker on peach twig $^{1)}$ as well as Japanese pear canker and apple canker ${ }^{13)}$. Isolates of the peach Phomopsis rot fungus consist of two groups of colony morphology, the W- and G-types. Alpha conidia of $P$. amygdali ${ }^{23)}$, a Phomopsis sp. isolated from peach Phomopsis rot $^{1,13,18,19)}$ and isolates from peach Fusicoccum canker in Japan ${ }^{10)}$ were morphologically similar.

To determine the taxonomic status of the causal fungus of peach Fusicoccum canker in Niigata, we studied its morphological and pathological characters and compared them with those of $P$. amygdali and the W- and G-type isolates of Phomopsis sp. from peach and Japanese pear.

\section{MATERIALS AND METHODS}

Isolates The Peach Fusicoccum canker fungus and Phomopsis isolates used in this study are listed in Table 1. All these isolates were obtained from a single conidium or ascospore. Gift isolates were reisolated from a single conidium prior to use. The fungal isolates were kept for long storage by freezing the conidia at $-80^{\circ} \mathrm{C}$ in $10 \%$ glycerol solution. For routine maintenance of cultures, potato dextrose agar (PDA) (Difco) was used. To stimulate sporulation of the fungus, the agar leaf disk method ${ }^{14)}$ was utilized at intervals, i.e. the fungus was grown on $1.5 \%$ agar plate overlaid with boiled (for $45 \mathrm{sec}$ ) young leaves of peach or Japanese pear.

Morphological characters To observe conidial morphology, two culture methods were utilized : 1) each isolate was cultured on PDA plates at $25^{\circ} \mathrm{C}$ or $30^{\circ} \mathrm{C}$ under fluorescent lamps (12 hr cycle); and 2) each isolate was first grown on PDA plates at $25^{\circ} \mathrm{C}$ in the dark for about 5 days, when autoclaved one-year-old twigs (about $5 \mathrm{~cm}$ long) of peach or Japanese pear were placed on the plates and incubated at the same conditions for 5 more days. Then the twigs covered with mycelia were transferred to sterile test tubes $(18 \mathrm{~mm}$ in diameter and 180 $\mathrm{mm}$ in long) containing $2 \mathrm{ml}$ of sterile distilled water and incubated at $25^{\circ} \mathrm{C}$ or $30^{\circ} \mathrm{C}$ under fluorescent lamps $(12 \mathrm{hr}$ cycle) for conidial production. Conidiomata produced on inoculated twigs were sectioned using a freezing microtome (Leica, CM1100) to observe conidiomata and conidiophores. Conidia were mounted in water and observed under a light microscope. The size of 30 to 100 alpha, 30 to 100 beta conidia and 30 conidiophores were measured for each isolate.

To compare colony morphology, each isolate was grown on $9-\mathrm{cm}$ petri dishes containing $15 \mathrm{ml}$ PDA (Difco) and incubated for 14 days at $25^{\circ} \mathrm{C}$ under fluorescent lamps ( $12 \mathrm{hr}$ cycle) at about $4500 \mathrm{Lux}$.

Pathogenicity at bases of young peach shoots Approximately 5 to 6 weeks after the full bloom stage, bases of current season's shoots of potted peach trees
[Prunus persica (L.) Batsch var. vulgaris Maximowicz cv. Akatsuki] in the greenhouse or trees (cv. Fukushima Hakutou) in the orchard at the NIFTS in Tsukuba were sprayed with spore suspensions in $0.1 \%$ sucrose solution $\left(2 \times 10^{6}\right.$ alpha conidia/ml) with small atomizers. As a control, $0.1 \%$ sucrose solution was used. In the greenhouse tests, inoculated peach trees were incubated for 3 days under $95-100 \%$ R.H. at $23^{\circ} \mathrm{C}$ and then transferred to a greenhouse. In the field test, inoculated shoots were loosely wrapped with plastic bags and further covered with newspaper for 2 days to avoid direct sunshine. The diseased twigs were counted after 2 months in greenhouse tests and 3 months in field test.

Pathogenicity on peach, Japanese pear and apple twigs with wound Two-year-old twigs of peach (cv. Akatsuki) and apple (Malus pumila Miller var. domestica Schneider cv. Fuji) and 4-year-old branches of Japanese pear (Pyrus pyrifolia Nakai var. culta Nakai cv. Kousui) were inoculated in the orchard. In May, each twig was wounded with a knife by peeling off about $0.5 \mathrm{~cm}^{2}$ epidermal tissue, then mycelial discs, $12 \mathrm{~mm}$ in diameter, were placed on the wound and the disc on the wound area was wrapped with parafilm. As a control, a drop of distilled water was used instead of mycelial discs. The radius of the subsequent lesion was measured one month after inoculation. The experiment was carried out once with four to eight replications.

Pathogenicity on fruits Peach fruits (cv. Akatsuki) were covered with paper bags about 7 weeks after the full-bloom stage to protect them from fungicide sprays and/or natural infection. Approximately 11 to 13 weeks after the full-bloom stage, the bags were removed and about $5 \mathrm{ml}$ of a spore suspension $\left(4 \times 10^{6}\right.$ alpha conidia $/ \mathrm{ml}$ in $0.1 \%$ sucrose solution) was sprayed on the fruits with small atomizers. In control treatments, $0.1 \%$ sucrose solution was used instead of the spore suspension.

Inoculated fruits were covered again with paper bags containing a wet paper to keep the humidity high. One week before the ordinary harvesting stage (about 100 days after full bloom), the inoculated fruits were harvested and stored at $20^{\circ} \mathrm{C}$. The number of rotted fruits in each group of twelve fruits inoculated with a fungal isolate was counted until 13 days after harvesting. The experiment was conducted twice.

\section{RESULTS}

\section{Conidial morphology of peach Fusicoccum can- ker fungus}

Conidiophores are hyaline, cylindrical, sparingly branched, measuring $11.3-22.5 \times 1.5-2.5 \mu \mathrm{m}$ (Niigata 2) (Fig. 1A). Conidiogenous cells are enteroblastic and phialidic. Both alpha and beta conidia were produced on autoclaved twigs incubated at $30^{\circ} \mathrm{C}$ (Fig. 1B): alpha conidia are hyaline, fusiform to ellipsoidal, unicellular, usually biguttulate, measuring 4.6-8.6 $\times 2.3-3.5 \mu \mathrm{m}$; beta conidia are hyaline, filiform, hamate or straight, measuring $9.3-23.1 \times 0.7-2.0 \mu \mathrm{m}$ (Niigata $74-1$ ). Production of 
Table 1. Fungal isolates used in the present study with their pathogenicity on base of peach shoots

\begin{tabular}{|c|c|c|c|c|c|c|c|}
\hline & \multirow{2}{*}{ Isolate } & \multirow{2}{*}{ Origin } & \multirow{2}{*}{ Locality } & \multirow{2}{*}{ Collector } & \multicolumn{2}{|c|}{ Greenhouse $^{\text {a) }}$} & \multirow{2}{*}{$\begin{array}{l}\text { Field } \\
\text { test }^{\text {a) }}\end{array}$} \\
\hline & & & & & test I & test II & \\
\hline \multicolumn{8}{|c|}{ From peach Fusicoccum canker } \\
\hline 1 & Niigata $74-1$ & Peach twig, conidia & Niigata & Y. Yokoyama & & $6 / 14^{\mathrm{b})}$ & $11 / 20$ \\
\hline 2 & Niigata 2 & Peach twig, conidia & Niigata & Y. Yokoyama & $8 / 10$ & $12 / 15$ & $13 / 32$ \\
\hline \multicolumn{8}{|c|}{ Phomopsis amygdali } \\
\hline 3 & ATCC $42412^{\mathrm{c})}$ & Peach twig, conidia & France & F. Jailloux & & $15 / 16$ & \\
\hline \multicolumn{8}{|c|}{ Phomopsis sp. W-type } \\
\hline 4 & P-Pt-16 & Peach twig, ascospore & Ibaraki & S. Kanematsu & & & $0 / 26$ \\
\hline 5 & P-Pt-43 & Peach twig, conidia & Nagano & Y. Kawai & $0 / 5$ & $0 / 7$ & \\
\hline 6 & P-JP-18 & Japanese pear twig, ascospore & Ibaraki & S. Kanematsu & & $1 / 11$ & $0 / 18$ \\
\hline \multicolumn{8}{|c|}{ Phomopsis sp. G-type } \\
\hline 7 & $930811-14$ & Peach fruit, conidia & Ibaraki & A. Kudo & $0 / 5$ & $0 / 11$ & $0 / 19$ \\
\hline 8 & P-JP-24 & Japanese pear twig, conidia & Ibaraki & S. Kanematsu & & $0 / 13$ & $0 / 21$ \\
\hline
\end{tabular}

a) Base of current season's shoots was sprayed with spore suspensions of $2 \times 10^{6}$ alpha conidia $/ \mathrm{ml} 0.1 \%$ sucrose solution. Canker development was assessed about 2 and 3 months after inoculation in greenhouse and field, respectively.

b) Number of diseased shoots/number of inoculated shoots.

c) ATCC, American Type Culture Collection, Rockville, MD., U.S.A.

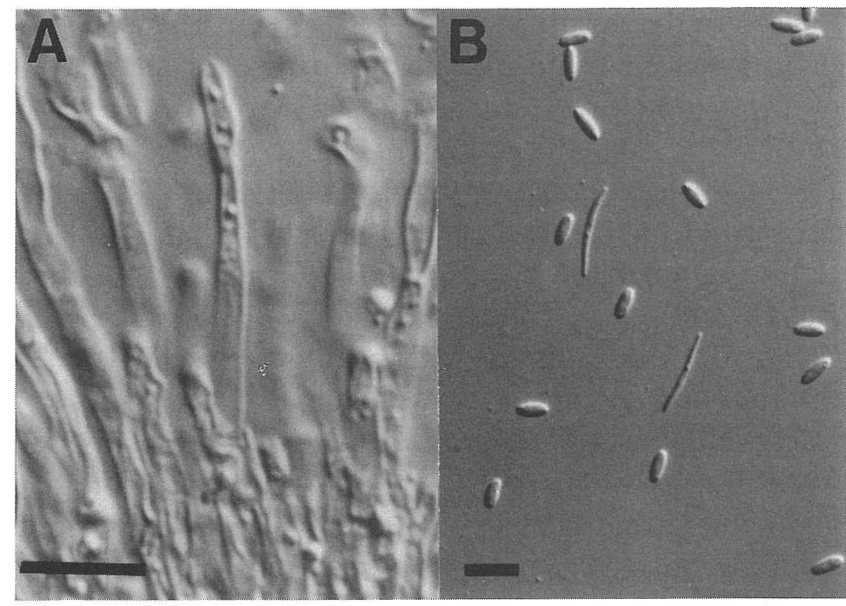

Fig. 1. Morphology of peach Fusicoccum canker fungus. A : Conidiophores (Niigata 2). B: Alpha and beta conidia (Niigata 74-1) formed on autoclaved twigs. Bar represents $10 \mu \mathrm{m}$.

beta conidia on autoclaved twigs was rare at $25^{\circ} \mathrm{C}$. On the contrary, beta conidia were not observed in cultures on PDA plates incubated at $25^{\circ} \mathrm{C}$ or $30^{\circ} \mathrm{C}$. Beta conidia did not germinate on $1.5 \%$ water agar and on PDA after incubation for $24 \mathrm{hr}$ at $25^{\circ} \mathrm{C}$.

\section{Colony morphology}

Colonies of the Niigata isolates from peach Fusicoccum canker were white and had a characteristic rosulate form. Pycnidial stromata with globose or applanate locules were observed on the lobes of rosulate mycelial growth (Plate I-A). Shizuoka isolates (Fu11 and Fu12) from peach Fusicoccum canker showed the same colony morphology (data not shown). On the other hand, colonies of $P$. amygdali from France (ATCC42412) were white but developed in a lobular form (Plate I-B). A $P$. amygdali isolate from almond in Italy (ATCC 42610) had the same colony morphology as the French isolate (data not shown).

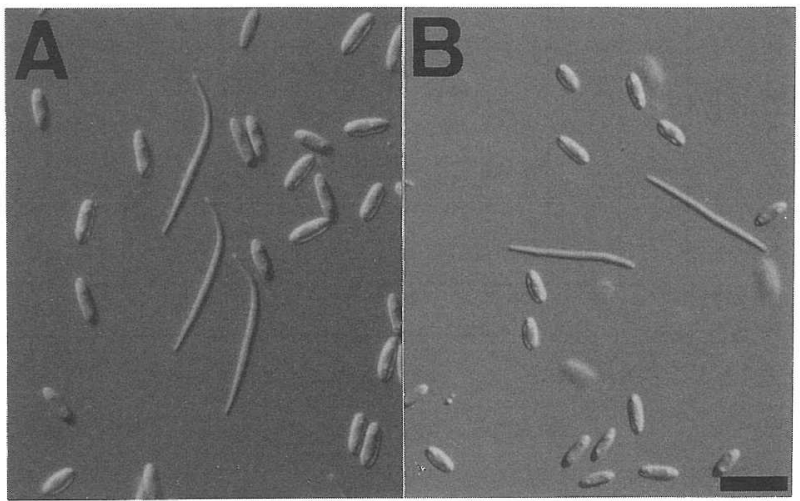

Fig. 2. Conidia of peach Phomopsis rot fungus formed on autoclaved twigs. A : W-type isolate (P-Pt16). B : G-type isolate (930811-14). Bar represents $10 \mu \mathrm{m}$.

\section{Pathogenicity}

Only the isolates from peach Fusicoccum canker (Niigata 74-1 and Niigata 2) and P. amygdali (ATCC 42412) incited a canker at the bases of current season's peach shoots in both greenhouse and field tests (Table 1). Symptoms caused by these fungi were very similar (Plate I-C, D). Cankers at the bases of twigs were slightly sunken, became brown to dark brown, and finally girdled the twig and produced longitudinal cracks on them.

The radius of the canker that developed on peach, Japanese pear and apple twigs with wounds varied with the fungi, Niigata isolates from peach Fusicoccum canker developed the biggest canker on peach twigs in particular as well as on Japanese pear and apple twigs (Fig. 3).

Incidence of peach fruit rot was compared after inoculations with isolates of the W- and G-types of Phomopsis and of the Niigata isolates from peach Fusicoccum canker (Table 2). The G-type isolate of Phomopsis caused a higher disease incidence than the W-type and Niigata isolates. Symptoms of fruit rot caused by iso- 

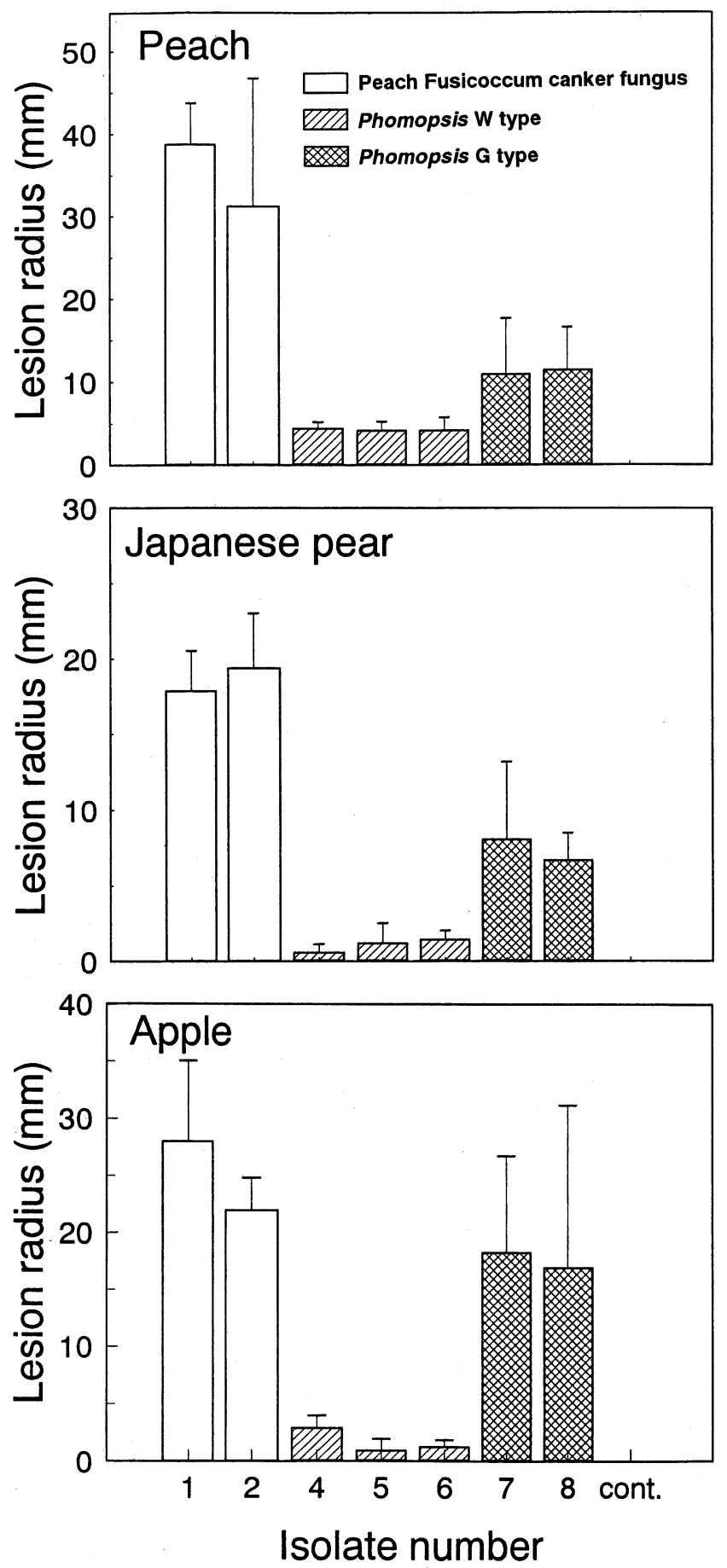

Fig. 3. Lesion development after field inoculations with peach Fusicoccum canker fungus and Phomopsis W- and G-types of isolates in artificially wounded 2-, 4- and 2-year-old twigs and branches of peach, Japanese pear and apple, respectively. Isolate numbers are the same as listed in Table 1 . The radius of the canker lesions was measured one month after inoculation. The experiment was carried out once with four to eight replications. Columns indicate the average radius of the canker lesions with standard errors.
Table 2. Incidence of fruit rot on peach in inoculation tests

\begin{tabular}{|c|c|c|c|}
\hline Isolate & & Test $\mathrm{I}^{\mathrm{a})}$ & Test II ${ }^{a)}$ \\
\hline $\begin{array}{l}\text { Peach Fusicoccum } \\
\text { canker fungus }\end{array}$ & Niigata 2 & $50 \%$ b) & $27 \%$ \\
\hline Phomopsis sp. W-type & P-Pt-16 & 40 & 33 \\
\hline Phomopsis sp. G-type & $930811-14$ & 82 & 89 \\
\hline Control & & 0 & 0 \\
\hline
\end{tabular}

a) Peach fruits were sprayed with $5 \mathrm{ml}$ of aqueous suspensions of $4 \times 10^{6}$ alpha conidia $/ \mathrm{ml}$ of $0.1 \%$ sucrose. Control was treated only with $0.1 \%$ sucrose solution.

b) Diseased fruits were counted until 13 days after harvest. Disease incidence was shown with percentage of diseased fruits.

lates of the W- and G-types Phomopsis and by the Niigata isolates were all similar and indistinguishable.

\section{DISCUSSION}

Despite the unsatisfactory state of our knowledge of fungi given the name Fusicoccum, its use for anamorphs of some species of Botryosphaeria seems to be justified $^{3,11,15-17)}$. On the other hand, the generic name Phomopsis had not been correctly typified for a long time because of the absence of the lectotype for the genus ${ }^{21}$. Later, an amended proposal that Phomopsis (Saccardo) Bubák was to be conserved, with Phomopsis lactucae (Saccardo) Bubák as the lectotype, was accepted at the International Botanical Congress in 198725).

The Niigata isolates from peach Fusicoccum canker were distinctly different from Botryosphaeria in colony and conidial morphology. As the isolates had phialidic conidiogenous cells and bore beta conidia typical of the genus Phomopsis in vitro (Fig. 1), we judged that the Niigata isolates do not belong to the genus Fusicoccum but to the genus Phomopsis, although we could not find the ascogenous stage of the fungi in the orchards.

We compared the morphology of alpha conidia, colony characters and disease symptoms of the Niigata isolates with those of the Kanagawa isolates described by Harada and Kagiwata (1951), as well as those of the Shizuoka isolates (Fu11 and 12), kindly given by Dr. Serizawa. We concluded that the causal agents of peach Fusicoccum canker in Japan are identical and belong to the same species.

In Japan, Phomopsis isolates from peach Phomopsis rot consist of two groups, W- and G-types ${ }^{13}$. Morphology of alpha conidia of these Phomopsis isolates was similar to that of the Niigata isolates from peach Fusicoccum canker. The shape of beta conidia of Niigata isolates was similar to that of the G-type isolates (930811-14 : 11$32.9 \times 1-2 \mu \mathrm{m}$ ) rather than to the W-type isolates (P-Pt16 : 19.5-31.7 $\times 1-2 \mu \mathrm{m}$ ) (Fig. 2). Beta conidia of G-type isolates were not observed on PDA cultured at $25^{\circ} \mathrm{C}^{13}$ ) but were produced on PDA or autoclaved twigs at $30^{\circ} \mathrm{C}$. On the other hand, colony morphology and pathogenicity to peach shoots of the peach Fusicoccum 
canker fungus were different from both W- and G-types of isolates. The typical symptom, canker on the base of peach shoot, was reproduced by the Niigata isolates and a French $P$. amygdali isolate but not by W- and G-type isolates of Phomopsis sp. (Table 1). Therefore, the fungus from peach Fusicoccum canker in Japan is best identified as $P$. amygdali.

Niigata isolates from peach Fusicoccum canker and $P$. amygdali used in this study failed to produce beta conidia on PDA plates in all culture conditions used. Tuset and Portilla (1989) found beta conidia of $P$. amygdali only on extremely dehydrated leaves but not in vitro $^{23)}$. We observed beta conidia of Niigata isolates on autoclaved twigs in vitro (Fig. 1B).

Peach Phomopsis rot fungus causes peach twig canker around buds, as the fungus generally enters through either dead buds or dead tissues around the bud ${ }^{1,18)}$. In our experiment, isolates from peach Phomopsis rot could not develop canker lesion on the base of the current season's peach shoots, whereas Niigata isolates and $P$. amygdali caused typical symptoms of peach Fusicoccum canker on peach twigs without any apparent wound (Table 1). On the other hand, the Niigata isolates and the Phomopsis W- and G-type isolates were distinct in pathogenicity on twigs of peach, Japanese pear and apple. Niigata isolates were highly virulent on these hosts, whereas Phomopsis W-type isolates were weakly pathogenic. Phomopsis G-type isolates were moderately virulent, as already reported ${ }^{13)}$. Phomopsis isolates of the $\mathrm{W}$ - and G-types have also been obtained from Japanese pear canker and apple canker ${ }^{13)}$. From these results, the causal agent of peach Fusicoccum canker might be able to infect Japanese pear and apple trees in the orchard. Similar results were reported by Uddin et al. (1998). Isolates of Phomopsis sp. causing shoot blight of peach in Georgia, USA, could infect twigs of apple, plum and pear after artificial inoculation, in contrast to other Phomopsis isolates from plum and Japanese pear which developed significantly smaller cankers on peach ${ }^{24)}$. To explore the genetic identity or relatedness of these groups of fungi, DNA analyses of the Niigata $P$. amygdali isolates and W- and G-types of Phomopsis isolates are in progress.

We wish to thank Dr. H. Ishii, National Institute of AgroEnvironmental Sciences, for critically reading the manuscript. Also, we are grateful to Ms. Y. Furuya, National Institute of Fruit Tree Science, for her technical assistance.

\section{Literature cited}

1. Abiko, K. (1972). Ecological studies on the peach Phomopsis rot. Bull. Hortic. Res. Stn. Ser. A11 : 127-137 (in Japanese).

2. Balio, A., Chain, E.B., De Leo, P., Erlanger, B.F., Mauri, M. and Tonolo, A. (1964). Fusicoccin: a new wilting toxin produced by Fusicoccum amygdali Del. Nature $203: 297$
3. Butin, H. (1993). Morphological adaptation and spore pleomorphism in the form-complex DichomeraCamarosporium and Fusicoccum-Dothiorella. Sydowia $45: 161-166$.

4. Cohoon, D.F. and Daines, R.H. (1956). Peach canker (Fusicoccum amygdali): times and sites of infections. Plant Dis. Rep. 40 : 304-308.

5. Corda, A.C.I. (1829). Sturm's Deutschlands Flora 2: 111.

6. Daines, R.H., Cohoon, D.F., Leone, I. and Brennan, E. (1958). Control of Fusicoccum canker of peach by nutrition, defoliation, and protective fungicides. Phytopathology $48: 347-390$.

7. Delacroix, G. (1905). Sur une maladie des amandiers en Provence. Bull. Trimest. Soc. Mycol. Fr. 21 : 180-185 (in French).

8. Guba, E.F. (1953). Large leaf spot and canker of peach caused by the fungus Fusicoccum amygdali Delarc. Plant Dis. Rep. 37 : $560-564$.

9. Harada, S. (1952). The spread of peach Fusicoccum canker and present state of its control. Plant Prot. 6: 415-417 (in Japanese).

10. Harada, S. and Kagiwata, T. (1951). Studies in new peach disease "edaorebyo". Bull. Kanagawa Prefect. Norinbu : 1-17 (in Japanese).

11. Jacobs, K.A. and Rehner, S.A. (1998). Comparison of cultural and morphological characters and ITS sequences in anamorph of Botryosphaeria and related taxa. Mycologia 90 : 601-610.

12. Jailloux, F. and Froidefond, G. (1978). Susceptibility of peach leaf-scars to Fusicoccum amygdali Del. : influence of inoculum and leaf-fall stage. Ann. Phytopathol. 10: $39-44$.

13. Kanematsu, S., Kobayashi, T., Kudo, A. and Ohtsu, Y. (1999). Conidial morphology, pathogenicity and cultural characteristics of Phomopsis isolates from peach, Japanese pear and apple in Japan. Ann. Phytopathol. Soc. Jpn. 65 : 264-273.

14. Kishi, K. (1995). Production of pycnidia and pycnospore by Agar Leaf Disk Method. Plant Prot. 49 : 129-130 (in Japanese).

15. Morgan-Jones, G. and White, J.F., Jr. (1987). Notes on coelomycetes. II. Concerning the Fusicoccum anamorph of Botryosphaeria ribis. Mycotaxon : 117-125.

16. Pennycook, S.R. and Samuels, G.J. (1985). Botryosphaeria and Fusicoccum species associated with ripe fruit rot of Actinidia deliciosa (kiwifruit) in New Zealand. Mycotaxon 24 : 445-458.

17. Radziah, N.Z. and Chee, K.H. (1989). A new foliar disease of rubber. Plant Pathol. 38 : 293-296.

18. Roberts, J.W. (1940). The constriction disease of peach. Phytopathology 30 : 963-968.

19. Rosenberger, D.A. and Burr, T.J. (1982). Fruit decays of peach and apple caused by Phomopsis mali. Plant Dis. 66 : 1073-1075.

20. Serizawa, S. (1984). Ecological studies on Fusicoccum canker (Fusicoccum sp.) of peach tree. Bull. Shizuoka Citrus Exp. Stn. 20 : 31-43 (in Japanese).

21. Sutton, B.C. (1980). The Coelomycetes. Commonwealth Mycological Institute, Kew, Surrey, England, pp. 164166. 
22. Togashi, K., Harada, S. and Kagiwata, T. (1952). Notes on peach Fusicoccum canker. Ann. Phytopathol. Soc. Jpn. 16 : 147 (Abstr. in Japanese).

23. Tuset, J.J. and Portilla, M.T. (1989). Taxonomic status of Fusicoccum amygdali and Phomopsis amygdalina. Can. J. Bot. 67 : 1275-1280.

24. Uddin, W., Stevenson, K.L., Pardo-Schultheiss, R.A. and Rehner, S.A. (1998). Pathogenic and molecular characterization of three Phomopsis isolates from peach, plum, and Asian pear. Plant Dis. 82 : 732-737.

25. Uecker, F.A. (1988). A World List of Phomopsis Names with Notes on Nomenclature, Morphology and Biology, Cramer Publishers, Berlin.

\section{和 文 摘 要}

兼松聡子・横山泰裕・小林享夫・工藤

泉・大津善弘：日本産
モモ枝折病菌の再同定

モモ枝折病は従来, Fusicoccum 属菌による病害とされていた が，新潟県において発生した罹病樹から分離された菌株の分生 子形成細胞はフィアライドであり, in vitro で Phomopsis 属菌 に特徵的な $\beta$ 胞子を形成したことから，本菌はFusicoccum 属 菌ではなく, Phomopsis 属菌であると考えられた。この新潟分離 株と，フランスで分離されたモモに canker 引きき起こす $P$. amygdali (synonym:F. amygdali), および本邦産でモモに果実 腐敗や芽枯れ症状を引き起こすPhomopsis 属菌の W 型株と G 型株とを用いて, 胞子形態, コロニーの形態,ならびにモモ新梢 基部に対する病原性を比較した.その結果，モモ枝折病菌は，コ ロニー形態が白色で特徴的な隆起があること，およびモモ新梢 基部に特徴的な病徴を示すこと，の 2 点において，W 型株や $\mathrm{G}$ 型株とは異なった。しかし，欧州産のP. amygdali (Delacroix) Tuset et Portilla には諸性質が似ており，これと同一種である と同定した。

\section{Plate I}
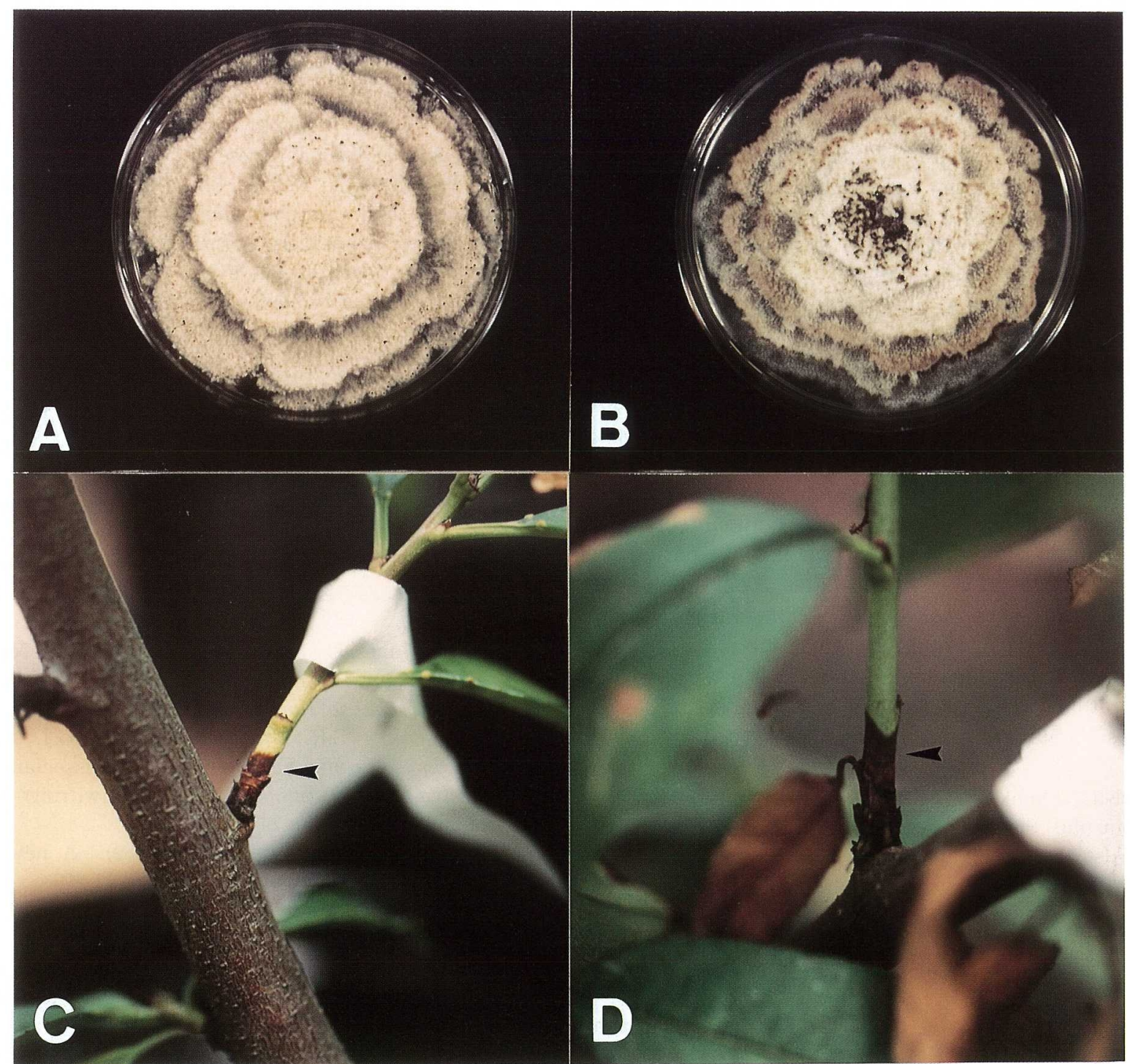

Plate I

A and B : Colonies of peach Fusicoccum canker fungus. A : Niigata 74-1 and B: ATCC42412 on PDA, grown for 2 weeks at $25^{\circ} \mathrm{C}$. C and D : Cankers on the base of young peach shoot (black arrow) after inoculation with the peach Fusicoccum canker fungus (Niigata 2) (C) and Phomopsis amygdali (ATCC42412) (D). 